\title{
The Correlation between Family Characteristics and Husband and Wife Interaction during the Covid-19 Pandemic
}

\author{
Risda Rizkillah ${ }^{1 *}$, Diah Krisnatuti ${ }^{2}$, Tin Herawati ${ }^{3}$ \\ ${ }^{1,2,3}$ Department of Family and Consumer Sciences, Faculty of Human Ecology, IPB University, \\ Bogor 16680, West Java, Indonesia \\ *) Corresponding author: risdarizkillah@ @apps.ipb.ac.id
}

\begin{abstract}
Pandemics not only can facilitate a special space for husband-wife and child relationships but also a significant stressor for most husbands and wives and children. This study aimed to analyze the relationship between family characteristics and husband-wife interactions during the Covid-19 pandemic. This study used a cross-sectional study design and conducted in JuneNovember 2020. The respondent in this study was a wife from an intact family who has elementary school-senior high school-age children (SD-SMA). The number of respondents in this study was 452 respondents. Data collection in this study was carried out using google form. Based on the research result, the highest means of index owned by the love dimension and the smallest index owned by respect's dimension. There are significant differences between HEL wife and LEL wife in love dimension, respect dimensions, and a total of husband-wife interaction. The correlation test shows that there is a significant negative correlation between husband's age, wife's age, and the number of children with husband-wife interaction. Furthermore, the correlation test also shows that the husband's income positively correlates with husband-wife interaction. This study concludes that women's higher education and husband's high income can make husband and wife interaction better.
\end{abstract}

Keywords: communication, covid-19, education level, husband-wife interaction

\begin{abstract}
Abstrak
Pandemi tidak hanya dapat memfasilitasi ruang khusus untuk hubungan suami-istri dan anak, tetapi juga menjadi pemicu stres yang signifikan bagi sebagian besar suami dan istri serta anakanak. Tujuan penelitian ini adalah untuk menganalisis hubungan karakteristik keluarga dengan interaksi suami-istri selama pandemi Covid-19. Penelitian ini menggunakan desain penelitian cross-sectional dan dilaksanakan pada bulan Juni-November 2020. Responden dalam penelitian ini adalah seorang istri dari keluarga utuh yang memiliki anak usia Sekolah Dasar-Sekolah Menengah Atas (SD-SMA). Jumlah responden dalam penelitian ini sebanyak 452 responden. Pengumpulan data dalam penelitian ini dilakukan dengan menggunakan google form. Berdasarkan hasil penelitian, indeks rata-rata tertinggi dimiliki oleh dimensi cinta dan indeks terkecil dimiliki oleh dimensi menghargai. Ada perbedaan yang signifikan antara istri dengan tingkat Pendidikan tinggi (HEL) dan istri dengan tingkat pendidikan rendah (LEL) dalam dimensi cinta, dimensi menghargai, dan total interaksi suami-istri. Uji korelasi menunjukkan bahwa ada hubungan negatif yang signifikan antara umur suami, umur istri, dan jumlah anak dengan interaksi suami-istri. Selain itu, uji korelasi juga menunjukkan bahwa pendapatan suami memiliki hubungan yang signifikan positif dengan interaksi suami-istri. Simpulan dari penelitian ini adalah pendidikan tinggi yang dimiliki wanita dan pendapatan tinggi yang dimiliki suami membuat interaksi suami dan istri semakin baik.
\end{abstract}

Kata kunci: covid-19, komunikasi, interaksi suami-istri, tingkat pendidikan 


\section{Introduction}

In early 2020, starting from the City of Wuhan, China, the whole world is currently facing the global pandemic COVID-19. COVID-19 or Coronavirus Disease 2019 is a new outbreak caused by the Sars-CoV-2 virus that has never been recognized in humans before (Ministry of Health, 2020). Since the case was first discovered in early March 2020, the Indonesian government has advised on health protocols or adaptation of new habits that all levels of society must obey without exception. One of the policies issued by the government is Large-Scale Social Restrictions (PSBB). This policy requires the public to survey various activities such as studying, working, and basic from home so that roles that are usually carried out in schools, certain institutions are now centred on families (Anhusadar, 2020). The COVID-19 pandemic has also changed the work system in organizations by preventing employees from working in offices and gathering in a room by imposing a Work From Home (WFH) work system, which has not become a work culture in Indonesia before (Mustajab, Bauw, Rasyid, Irawan, Akbar, \& Hamid, 2020). Based on BPS data (2020), economic conditions in Indonesia in quarter 1 in 2020 have decreased by 1.01 per cent compared to the 4th quarter of 2019. This condition is one of the direct impacts of the suspension of economic activities due to the social distancing policy as a first step to prevent the spread of the Covid-19 virus. Apart from impacting the economic downturn, social distancing policies have also caused companies to lay off employees or often called termination of employment (PHK), thereby increasing the risk of unemployment. Recorded in February 2020, Indonesia's unemployment rate has reached 4.99 per cent or 6.88 million people (BPS 2020).

Based on data from the Ministry of Women Empowerment and Child Protection in Indonesia, during 2021, 3552 domestic violence cases were reported. During the Covid-19 pandemic, families are more at risk of experiencing cases of domestic violence. Based on data from Susenas 2015 and 2020, the divorce rate in Indonesia continues to increase. In 2015, 5.89 per cent of married couples were divorced (living). The number is about 3.9 million out of a total of 67.2 million households (Maharrani, 2021). The increase in divorce cases indicates that married couples are not optimal in family, work, and time roles. Family interactions cannot run well, causing a lack of satisfaction with marriage quality (Herawati, Kumalasari, Musthofa., \& Tyas 2018).

Pandemics can facilitate a special space for husband-wife and child relationships (Gambin et al., 2020). Still, on the other hand, it is also a significant stressor for most husbands and wives and children (Brown, Doom, Lechuga-Pe na, Watamura, \& Kopples, 2020). Interaction is one way for families to organize themselves in carrying out activities that provide characteristics to survive in certain groups and conditions (Aldous, 1977). Family interactions exist between family members, including husbandwife interactions, mother-child interactions, and father-child interactions involving communication and emotional bonding to understand better family roles and functions (Puspitawati \& Setioningsih, 2011; Waldinger \& Schulz, 2006). The interaction of husband and wife has benefits to maintain the harmony of family functions, especially in terms of the division of roles, tasks and jobs (Puspitawati, 2012). In addition, The limited time between mother and child will affect the development of children, which is one of the causes of families with husband and wife working (Puspitawati \& Setioningsih 2011). Interaction and mutual openness are some of the keys to optimizing the quality of marriage. (Wheathly, 2014). Marriage happiness is achieved through 
communication and openness between the spouse and the partner's family to maintain marital commitment (Rizkillah, 2014; Tyas \& Herawati, 2017).

Previous research has shown that family interactions have a significant relationship with family size, where the more the number of family members, the better the interaction within the family (Herawati, Kumalasari, Musthofa, \& Tyas, 2018). Husband and wife interaction also has a significant positive relationship with father's education and mother's education and significantly negatively related to father's age, meaning that the education of fathers and mothers is high and younger fathers have better husband-wife interactions (Rachman, 2019). Several researchers have researched husband-wife interactions, but portraits of husband-wife interactions and their differences based on wife's education during the pandemic have never been carried out. Therefore, the researcher aims to identify family characteristics and husband-wife interactions during the Covid-19 pandemic, analyze differences in husband-wife interactions based on the level of education of the wife, and analyze the relationship between family characteristics and husband-wife interactions during the Covid-19 pandemic.

\section{Methods}

\section{Participants}

This study used a cross-sectional study design, namely research conducted in a certain period. This research is an online survey conducted using a questionnaire. The study was conducted in June-November 2020. In this study, the sampling technique was carried out non-probability sampling is by purposive sampling technique. The respondent in this study was a wife from an intact family who has elementary schoolsenior high school-age children (SD-SMA). The number of respondents in this study was 452 respondents.

\section{Measurement}

Data collection in this study was carried out using google form, which is distributed through several social media such as Whatsapp, Instagram, and Facebook. The questionnaire distributed contains family characteristics, namely the age of husband and wife (years), education level of husband and wife (years), husband-wife income, husband-wife occupation, number of family members, and children. Husband's age is a number that shows the husband's stated length of life in years. Wife's age is a number that shows the wife's stated length of life in years. Husband's education is the last level of formal education taken by husband (years). Wife's education is the last level of formal education taken by the wife wife (years). Husband and wife's income is the amount of money received by a husband or wife in one month. The number of family members is the number of people living in the house.

Husband and wife interaction is the relationship between husband and wife, seen from communication and bonding and measured based on the dimensions of love, directing, and respect. Husband and wife in this study is a modification of the instrument from Chuang in Rambe (2015) which measures interactions based on three dimensions, namely love consisting of 8 items, directing consisting of 5 items, and respect consisting of 6 items. The answer scale uses a Likert scale consisting of $1=$ 
never; $2=$ rarely; $3=$ often; $4=$ always. The total number of question items was 19 items with a Cronbach alpha of 0.893 .

\section{Analysis}

This study uses primary data. Primary data is data obtained directly from the original source. Data processing and analysis were performed using Microsoft Excel and Software Statistical Product and Service Solution 26 (SPSS) and carried out through several steps: entering, cleaning, scoring, analyzing, and data interpretation. The scoring step based on the score then transformed into an index. The categorization of the index on the husband-wife interaction variable is divided into three categories: low, medium, and high categories, which are categorized based on the cut-off categorization by Sunarti et al. (2005), namely <60 low categories, 60-79 moderate categories, $\geq 80$ categories high. The analysis used in this research is descriptive, analysis of differences in independent sample T-test, and Pearson correlation analysis.

\section{Findings}

\section{Family Characteristics}

Research results show based on mother's level of education, namely Low-Level education (LEL) is mother's who just has the level of education maximum senior high school, while High Education Level (HEL) is mother's who has the level of education more than senior high school (D3/S1/S2/S3). Based on the research result, the husband's age in this research around 22 until 66 years old, with means 46.35 years old, while the wife's age has ranged from around 21 to 61 years old with means 42.86 years old. The average husband's income with HEL wife (Rp8.766.880) is higher than a husband with LEL wife (Rp4.021.550,-). The average wife's income in HEL wife (Rp4.282.910,-) is higher than LEL wife (Rp1.202.980,-). The average of a family member as much as four people and the number of children as much as two children (Table 1).

Table 1. Distribution of Family Characteristics Data based on Mother's Level of Education (LEL and HEL)

\begin{tabular}{|c|c|c|c|c|c|c|}
\hline \multirow{2}{*}{ Category } & \multicolumn{2}{|c|}{ LEL $(n=218)$} & \multicolumn{2}{|c|}{$\operatorname{HEL}(n=234)$} & \multicolumn{2}{|c|}{ Total $(n=452)$} \\
\hline & Min-Max & Mean & Min-Max & Mean & Min-Max & Mean \\
\hline Husband's age (years) & $27-64$ & 47.22 & $22-66$ & 45.53 & $22-66$ & 46.35 \\
\hline Wife's age (years) & $25-60$ & 42.89 & $21-61$ & 42.84 & $21-61$ & 42.86 \\
\hline $\begin{array}{l}\text { Wife's income } \\
\text { (thousand rupiah) }\end{array}$ & $0-45000$ & 1202.98 & $0-150000$ & 4282.91 & $0-150000$ & 2797.455 \\
\hline $\begin{array}{l}\text { Husband's income } \\
\text { (thousand rupiah) }\end{array}$ & $0-25000$ & 4021.55 & $0-65000$ & 8766.88 & $0-65000$ & 6478.205 \\
\hline Family Size (person) & $0-8$ & 4.38 & $0-9$ & 4.37 & $0-9$ & 4.38 \\
\hline $\begin{array}{l}\text { Number of children } \\
\text { (person) }\end{array}$ & $1-8$ & 2.77 & $1-8$ & 2.66 & $1-8$ & 2.71 \\
\hline
\end{tabular}

The mother's type of job in this research divided into working mom and not working mom. Based on the mother's type of job, almost half the wife is not a working mom $(43.7 \%)$ and more than half the wife is a working mom (56.3\%). In working moms, there is some type of job. Almost one-fifth (17.9\%) working moms work as civil 
servants/TNI/POLRI. Other types of work the wife has are private employees (12.8\%), entrepreneur $(10.2 \%)$, farmer $(2.6 \%)$, freelance $(0.9 \%)$, and others $(11.3 \%)$ (Figure 1$)$.

\section{Mother's Type of Job}
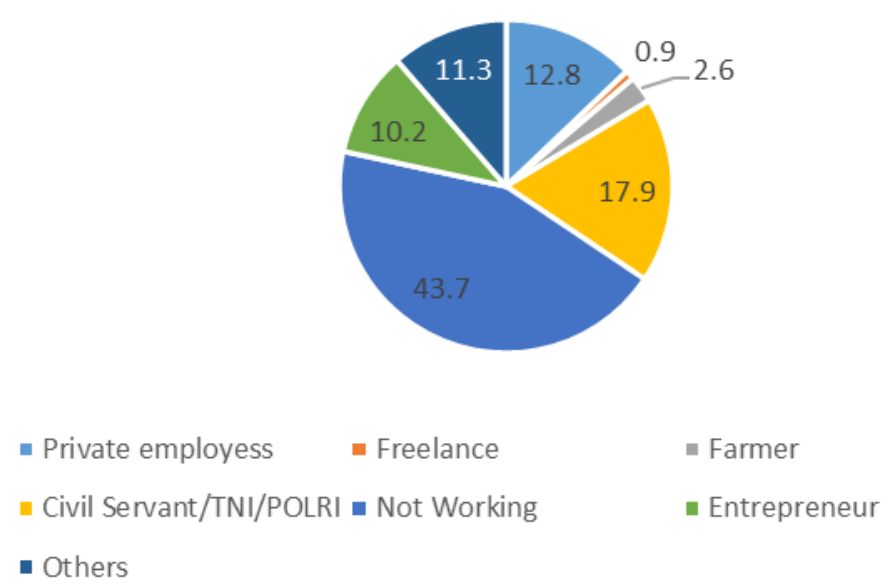

Figure 1. Distribution of Mother's Type of Job

Based on the type of job of the husband, one-third of husbands have private employees (33.3\%). More than a fifth $(22.7 \%)$ and $(20.8 \%)$ husbands work as civil servants/TNI/POLRI and entrepreneurs. Although the number is small, some husbands work as farmers $(3.8 \%)$, retire $(3.1 \%)$, do not work $(1.1 \%)$, and fishermen $(0.2 \%)$ (Figure 2).

\section{Father's Type of Job}

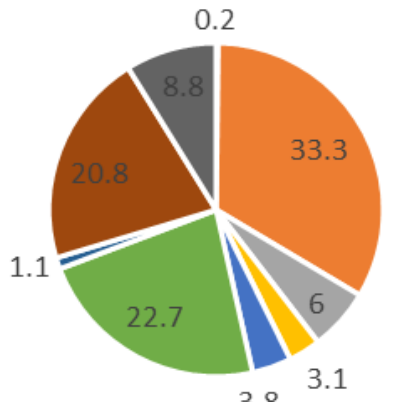

\footnotetext{
- Fisherman

- Retired

- Not Working
}

$$
\begin{aligned}
& \text { - Private employess } \\
& \text { - Farmer } \\
& \text { - Entrepreneur }
\end{aligned}
$$$$
\text { - Freelance }
$$$$
\text { - Civil Servant/TNI/POLRI }
$$$$
\text { - Others }
$$

Figure 2. Distribution of Father's Type of Job 


\section{Husband-Wife Interaction}

Based on research results in the dimension of love/nurturing, more than half LEL wife $(52.3 \%)$ and HEL wife $(62.4 \%)$ always show affection to their husbands. Based on the different test result, there is a significant differences between HEL wife and LEL wife in showing affection to husband and love to hug husband, which is HEL wife (3.52 \& 3.35) has a higher score than and LEL Wife (3.37\&3.05) in showing affection to husband and love to hug husband. Almost half of LEL wife (45.4\%) and HEL wife (44.9\%) always help husband with things or solve their problems. More than half of HEL wife (66.2\%) and LEL wife (64.7\%) trust their husband. Almost half LEL wife $(48.2 \%)$ and more than half HEL wife $(53.0 \%)$ always help out husband with suggestion when their husband needs a solution. However, in making breakfast with husband, one fifth LEL wife $(20.6 \%)$ and HEL wife $(18.8 \%)$ rarely do that. Almost on fifth LEL wife (17.4\%) and HEL wife (16.7\%) rarely feels that husband can make them feel calm when they feel sad.

Table 2. Different Test Results Independent Sample T-Test Husband-Wife Interaction (Item) Based on Mother's Level of Education (LEL and HEL)

\begin{tabular}{|c|c|c|c|c|c|c|c|c|c|c|c|}
\hline \multirow[t]{2}{*}{ Statement } & \multicolumn{4}{|c|}{ LEL $(\mathrm{n}=218)$} & \multicolumn{4}{|c|}{ HEL $(n=234)$} & \multicolumn{3}{|c|}{$\begin{array}{l}\text { Average Difference Test } \\
\text { Mean }\end{array}$} \\
\hline & 1 & 2 & 3 & 4 & 1 & 2 & 3 & 4 & LEL & HEL & $\mathrm{p}$-value \\
\hline \multicolumn{12}{|l|}{ LOVE } \\
\hline $\begin{array}{l}\text { I show affection for my } \\
\text { husband }\end{array}$ & 0.5 & 14.7 & 32.6 & 52.3 & 0.4 & $9 . .4$ & 27.8 & 62.4 & 3.37 & 3.52 & $0.022 *$ \\
\hline $\begin{array}{l}\text { I like to help my } \\
\text { husband with things or } \\
\text { solve his problems }\end{array}$ & 0.9 & 13.8 & 39.9 & 45.4 & 0.0 & 17.5 & 37.6 & 44.9 & 3.30 & 3.27 & 0.723 \\
\hline $\begin{array}{l}\text { I make time for breakfast } \\
\text { with my husband }\end{array}$ & 4.1 & 20.6 & 27.5 & 47.7 & 2.1 & 18.8 & 27.8 & 51.3 & 3.19 & 3.28 & 0.253 \\
\hline $\begin{array}{l}\text { I make time for dinner } \\
\text { with my husband }\end{array}$ & 3.2 & 13.8 & 36.7 & 46.3 & 0.4 & 13.7 & 32.1 & 53.8 & 3.26 & 3.39 & 0.072 \\
\hline $\begin{array}{l}\text { When my husband needs } \\
\text { a solution to his } \\
\text { problem, I help out with } \\
\text { suggestions }\end{array}$ & 0.9 & 8.3 & 42.7 & 48.2 & 0.4 & 9.0 & 37.6 & 53.0 & 3.38 & 3.43 & 0.423 \\
\hline $\begin{array}{l}\text { When I feel sad, my } \\
\text { husband makes me feel } \\
\text { calm }\end{array}$ & 2.3 & 17.4 & 44.5 & 35.8 & 0.9 & 16.7 & 36.3 & 46.2 & 3.14 & 3.28 & 0.055 \\
\hline I love to hug husband & 3.2 & 24.8 & 35.8 & 36.2 & 0.9 & 15.8 & 30.8 & 52.6 & 3.05 & 3.35 & $0.000^{* * *}$ \\
\hline I really trust husband & 0.9 & 6.4 & 28.0 & 64.7 & 0.0 & 6.8 & 26.9 & 66.2 & 3.56 & 3.59 & 0.619 \\
\hline DIRECTING & & & & & & & & & & & \\
\hline $\begin{array}{l}\text { I remind my husband to } \\
\text { do the work he had to do }\end{array}$ & 2.8 & 10.1 & 38.5 & 48.6 & 2.1 & 20.5 & 38.5 & 38.9 & 3.33 & 3.14 & $0.012^{*}$ \\
\hline $\begin{array}{l}\text { I remind my husband } \\
\text { when he made a mistake }\end{array}$ & 1.4 & 5.5 & 42.2 & 50.9 & 0.4 & 12.8 & 40.6 & 46.2 & 3.43 & 3.32 & 0.116 \\
\hline $\begin{array}{l}\text { I made decisions for my } \\
\text { husband in important } \\
\text { situations }\end{array}$ & 2.3 & 27.1 & 40.8 & 29.8 & 1.7 & 27.8 & 38.0 & 32.5 & 2.98 & 3.01 & 0.686 \\
\hline $\begin{array}{l}\text { When I told my husband } \\
\text { not to do something, he } \\
\text { wouldn't do it }\end{array}$ & 3.7 & 39.0 & 42.2 & 15.1 & 0.9 & 36.8 & 44.9 & 17.5 & 2.69 & 2.79 & 0.147 \\
\hline
\end{tabular}




\begin{tabular}{|c|c|c|c|c|c|c|c|c|c|c|c|}
\hline \multirow[t]{2}{*}{ Statement } & \multicolumn{4}{|c|}{ LEL $(n=218)$} & \multicolumn{4}{|c|}{ HEL $(n=234)$} & \multicolumn{3}{|c|}{$\begin{array}{l}\text { Average Difference Test } \\
\text { Mean }\end{array}$} \\
\hline & 1 & 2 & 3 & 4 & 1 & 2 & 3 & 4 & LEL & HEL & $\overline{p \text {-value }}$ \\
\hline $\begin{array}{l}\text { I often discuss with my } \\
\text { husband about the } \\
\text { children's school, and } \\
\text { other things about the } \\
\text { family }\end{array}$ & 0.9 & 6.9 & 26.6 & 65.6 & 0.0 & 4.7 & 25.6 & 69.7 & 3.57 & 3.65 & 0.167 \\
\hline RESPECT & & & & & & & & & & & \\
\hline I praise my husband & 3.2 & 35.8 & 34.9 & 26.1 & 0.9 & 34.6 & 33.8 & 30.8 & 2.84 & 2.94 & 0.185 \\
\hline $\begin{array}{l}\text { I feel safe letting my } \\
\text { husband make up his } \\
\text { mind }\end{array}$ & 2.8 & 22.5 & 44.5 & 30.3 & 1.3 & 20.9 & 41.0 & 36.8 & 3.02 & 3.13 & 0.142 \\
\hline $\begin{array}{l}\text { I love listening to my } \\
\text { husband's story }\end{array}$ & 1.8 & 8.7 & 35.3 & 54.1 & 0.0 & 7.7 & 34.6 & 57.7 & 3.42 & 3.50 & 0.199 \\
\hline $\begin{array}{l}\text { When I am with my } \\
\text { husband does not agree, } \\
\text { we discuss it with fine }\end{array}$ & 1.8 & 17.4 & 41.3 & 39.4 & 0.4 & 13.2 & 34.2 & 52.1 & 3.18 & 3.38 & $0.006 * *$ \\
\hline $\begin{array}{l}\text { My husband always does } \\
\text { what I ask him to do }\end{array}$ & 1.8 & 33.9 & 45.0 & 19.3 & 0.4 & 22.6 & 53.0 & 23.9 & 2.82 & 3.00 & $0.006 * *$ \\
\hline $\begin{array}{l}\text { I invite my husband / } \\
\text { family for recreation } \\
\text { together }\end{array}$ & 8.3 & 32.1 & 31.2 & 28.4 & 2.6 & 22.2 & 32.9 & 42.3 & 2.80 & 3.15 & $0.000 * *$ \\
\hline
\end{tabular}

Based on research result in the dimension of directing, there is a significant difference between HEL wife and LEL wife in reminding their husband to do the work he had to do, which is LEL wife (3.33) has a higher score than HEL wife (3.14). Almost half HEL wife $(48.6 \%)$ and more than one-third HEL wife $(38.9 \%)$ always remind their husband to do work he had to do. More than half LEL wife $(50.9 \%)$ and almost hal HEL wife $(46.2 \%)$ always remind their husband when he made a mistake. More than three out of five LEL wife (65.6\%) and HEL wife (69.7\%) always discuss with their husband about children's school and other things about the family. Almost half LEL wife (42.2\%) and HEL wife (44.9\%) often feels that when they told their husband not to do something, he wouldn't do it. However, more than one-fourth of LEL wife (27.1\%) and HEL wife $(27.8 \%)$ rarely made decisions for their husband in important situations.

Husband-wife interaction in the dimension of respect measured by six items and based on different test results there is a significant difference between LEL wife and HEL wife in three items, namely: 1) when I am with my husband does not agree, we discuss it with fine; 2) my husband always does what I ask him to do; 3) I invite my husband/family for recreation together. HEL wife has a higher score than LEL wife in all item. HEL wife more often than LEL wife in discussing with fine with their husband when she and her husband doesn't agree. HEL wife more often than LEL Wife in feeling that their husband always does what she asked him to do. HEL wife more often than LEL wife in inviting her husband/family for recreation together. More than half LEL Wife $(54.1 \%)$ and HEL wife (57.7\%) love listening to their husband's story. More than one-third LEL wife $(34.9 \%)$ and HEL wife $(34.6 \%)$ rarely praise her husband. More than one-fifth LEL wife (32.1\%) and HEL wife (22.2\%) rarely invite husband/family for recreation together. 
Based on the different test result, there is a significant difference between HEL wife and LEL wife in love's dimension $(\alpha=0.017)$, respect dimensions $(\alpha=0.001)$, and a total of husband-wife interaction $(\alpha=0.021)$. HEL wife has a higher index of love (79.68), index of respect (72.84), and a total of husband-wife interaction (75.71) than LEL wife $(76.03,67.10, \& 72.41)$. The minimum index of husband-wife interaction is 0 and the maximum index is 100 . The highest index is owned by love dimension (77.92) and the smallest index owned by respect's dimension (74.16) Tabel 3.

Table 3. Different Test Results Independent Sample T-Test Husband-Wife Interaction (Dimension \& Variable) Based on Mother's Level of Education (LEL and HEL)

\begin{tabular}{lccccc}
\hline \multirow{2}{*}{ Category } & \multirow{2}{*}{ Min-Max } & \multirow{2}{*}{ Total } & \multicolumn{2}{c}{ Mean } & \multirow{2}{*}{ P-Value } \\
\cline { 1 - 3 } & & & LEL & HEL & \\
\hline Love (Nurturing) & $0-100$ & 77.92 & 76.03 & 79.68 & $0.017^{*}$ \\
Directing & $0-100$ & 73.04 & 73.30 & 72.79 & 0.738 \\
Respect & $0-100$ & 70.07 & 67.10 & 72.84 & $0.001 * *$ \\
Husband-Wife Interaction & $0-100$ & 74.16 & 72.49 & 75.71 & $0.021^{*}$ \\
\hline
\end{tabular}

Note. $(*)$ significant at $\mathrm{p}<0.05,(* *)$ significant at $\mathrm{p}<0.001$; LEL: Maximum Senior High School, HEL: More than SHS (D3/S1/S2/S3)

Based on the research result, almost half the sample in the high category in love's dimension (45.8\%) and directing's the dimension (41.4\%). Almost half sample in the medium category $(48.0 \%)$ in husband-wife interaction and more than one-third sample $(35.6 \%)$ in the high category. Based on the mother's level of education. More than half LEL wife in the medium category in husband-wife interaction $(50.5 \%)$, only 31.2 per cent are in the high category. Almost half LEL wife in the medium category in love's dimension (46.3\%), directing's dimension (43.6\%), and respect's dimension (48.6\%). More than half HEL wife (52.1\%) in the high category in love's dimension and almost half in the medium category in directing's dimension (44.9\%), respect's dimension $(47.0 \%)$, and husband-wife interaction $(45.7 \%)$.

Table 4. Category of Husband-Wife Interaction

\begin{tabular}{|c|c|c|c|c|c|c|c|c|c|}
\hline \multirow[b]{2}{*}{ Category } & \multicolumn{3}{|c|}{ LEL } & \multicolumn{3}{|c|}{ HEL } & \multicolumn{3}{|c|}{ Total } \\
\hline & $\begin{array}{l}\text { Low } \\
(<60\end{array}$ & $\begin{array}{c}\text { Medium } \\
(60-79)\end{array}$ & $\begin{array}{l}\text { High } \\
(\geq 80)\end{array}$ & $\begin{array}{l}\text { Low } \\
(<60\end{array}$ & $\begin{array}{c}\text { Medium } \\
(60-79)\end{array}$ & $\begin{array}{l}\text { High } \\
(\geq 80)\end{array}$ & $\begin{array}{l}\text { Low } \\
(<60\end{array}$ & $\begin{array}{c}\text { Medium } \\
(60-79)\end{array}$ & High $(\geq 80)$ \\
\hline Love & 14.7 & 46.3 & 39.0 & 14.1 & 33.8 & 52.1 & 14.4 & 39.8 & 45.8 \\
\hline Directing & 12.8 & 43.6 & 43.6 & 15.8 & 44.9 & 39.3 & 14.4 & 44.2 & 41.4 \\
\hline Respect & 28.0 & 48.6 & 23.4 & 20.5 & 47.0 & 32.5 & 24.1 & 47.8 & 28.1 \\
\hline $\begin{array}{l}\text { Husband- } \\
\text { wife } \\
\text { interaction }\end{array}$ & 18.3 & 50.5 & 31.2 & 14.5 & 45.7 & 39.7 & 16.4 & 48.0 & 35.6 \\
\hline
\end{tabular}

The Correlation test shows a significant negative correlation between husband's age, wife's age, and the number of children with husband-wife interaction. It means that the younger age of husband and wife has higher husband-wife interaction than older husbands and wives. A family with few children has a higher husband-wife interaction. Furthermore, the correlation test also shows that a husband's income significantly correlates with husband-wife interaction. It means that the more the family has a high income, the better the husband-wife interaction. 
Table 5. Correlation between Family Characteristics and Husband-Wife Interaction

\begin{tabular}{lc}
\hline Variabel & Husband-Wife Interaction \\
\hline Husband's age (years) & $-0.157^{* *}$ \\
Wife's age (years) & $-0.115^{*}$ \\
Husband's income (thousand rupiah) & $0.135^{* *}$ \\
Number of children (person) & $-0.099^{*}$ \\
\hline Note. $\left.{ }^{*}\right)$ significant at $\left.p<0.05,{ }^{* *}\right)$ significant at $p<0.001$ &
\end{tabular}

\section{Discussions}

The interaction between husband and wife is very important in supporting the continuity of daily activities in the family. Husband-wife interaction is a reciprocal relationship between husband and wife in which there are several dimensions, namely love, directing, and respect (Chuang, 2005). Based on this study, the results of different tests show that husband-wife interaction, love's dimension, and respect dimension on HEL wife is higher than LEL wife. This is in line with Rizkillah, Sunarti, \& Herawati (2015) research, which states that wives with higher education have better academic, language and experience skills so that it is possible to have better interactions. In love's dimension, HEL wife has a higher score than and LEL Wife in showing affection to husband and love to hug husband. More than half of HEL wife and LEL wife show affection to husband and love to hug their husband. According to Zhafirah (2020), body language, seduction, jokes, hugs, kisses, and more intimate things make a married couple more intimate and make a happy marriage.

In respect's dimension, HEL wife more often than LEL wife in discussing with fine with their husband when she and her husband doesn't agree, feeling that their husband always does what she asked him to do, and inviting her husband/family for recreation together. This can happen because HEL wife has better income and education so that it can increase self-confidence when discussing with her husband and feels that her husband appreciates her by feeling that her husband always does what he asks. The results of previous research show that the higher a person's education, the easier it is to receive information so that the higher knowledge they have to encourage their ability to discuss and provide direction in an interaction (Jeniu, Widodo, \& Widiani, 2017). In addition, wives with higher education are easier to accept new things and make adjustments (Sholichah \& Anjarwati, 2015). Family income is also related to the creation of an active family environment (Zhang, 2012), which means that the higher the level of family income, the more active the interactions carried out by the family, one of which is by doing recreation, which HEL wife more often does. The result also shows that more than half LEL Wife and HEL wife love listening to their husband's story. This is in line with the research results of Herawati, Kumalasari, Musthofa, \& Tyas (2018), which also show that more than half of wives always make time to interact with their husbands and listen to their husbands' stories. A high score on these items can increase mutual trust and supportive attitudes, open attitude encourages mutual understanding, mutual respect and develops the quality of interpersonal relationships (Masturi, 2010; Rustan, 2013). Emotional intimacy and sexual satisfaction mediate the relationship between partners' assessment of their partner's communication and relationship satisfaction (Yoo, Bartle-Haring, Day, \& Gangamma, 2014). 
In directing's dimension, there is a significant difference between HEL wife and LEL wife in reminding their husband to do the work he had to do, which is LEL wife has higher score than HEL wife. Almost half LEL wife and more than one-third HEL wife always reminded their husband to do work he had to do. This statement shows the importance of responsibility in the life of husband and wife. In regulating the responsibilities between husband and wife, one of them is by reminding them that tasks that must be done are important things that are commonly done so that household life is directed, tasks are organized, and the noble goals of the family are easily achieved (Zhafirah, 2020). Moreover, more than half LEL wife and HEL wife always discuss the children's school with her husband and other things about the family. This of course, cannot be separated from efforts to adjust the needs of life and fulfill the responsibilities of raising children by parents (Hastuti, 2015).

The results showed that one-third family was included in the high family interaction category. The proportion with the highest category is in the love dimension, where almost half of the families are in the high category. This is in line with Zhafirah (2019) statement that the expression of love is the biggest human reaction in expressing love to their partner (the greatest expression of love for a relationship). Based on the proportion with the lowest category is in the respect dimension, where almost a quarter of the family is in a low category, this result is supported by the results which show that one-third wife never praises her husband and feel that her husband never does what she asked him to do. These results are in line with Rizkillah, Sunarti, and Herawati (2015) research, which shows that the lowest achievement in marital happiness is in praising a partner's ability.

Positive emotions during love are predicted relationship satisfaction in the future (Graber et al., 2011). In HEL wife, the proportion with the highest category is in the love dimension, where more than half of HEL wife is in the high category on that dimension. This can happen because in this study, more than half of the wives always show affection to husband, make time for breakfast and dinner with husband, help out husband with the suggestion when husband needs a solution, and love to hug husband. Furthermore, wives with a high level of education have been better intellectual level, which supports the wife's ability to provide suggestions for husbands and based on Sunarti, Rizkillah, Hakim, Zakiya, \& Damayanti (2021). The better the wife's education is, the more also good fulfilment of duties in the family. Meanwhile, for LEL wives, the proportion with the highest category was in the directing dimension, where nearly half of the LEL wives were in the high category on that dimension. This is supported by research results which show that more than half of LEL wives always remind her husband when he made a mistake and discuss with her husband about the children's school, and other things about the family.

The correlation test results show a significant negative relationship between husband's age, wife's age, and the number of children with husband-wife interaction. Younger husbands and wives have better husband-wife interactions. Ardian's (2019) research shows that the higher the father's age, the lower the husband-wife interaction. This result also in line with Larasati (2013), which states that the older wife or husband is a lower interaction in a family. The results also showed that the smaller the number of children, the better the husband-wife interaction in the family. The results of this study are supported by previous research, which states that the more dependents the family have, the higher the time spent on women (Eliana \& Ratina, 2007). This means that the smaller number of family members will make the wife more focused on interacting with 
her husband. The relationship test results also show a significant positive relationship between the husband's income and husband-wife interaction, where the higher the husband's income, the better the husband-wife interaction. This is supported by Baerholdt et al. (2012) suggest that low family income indicates that the family has few resources, which makes interactions within the family not optimal and can lead to conflicts within the family. Financial tension and stressful life events were the strongest correlations of negative communication, with higher stress levels predicting more negativity (Williamson, Karney, \& Bradbury, 2013). Families with higher incomes and higher education cooperate more often and share and make decisions independent of the allocation of money given (Iversen et al. 2011).

The limitation in this research is that the research does not include husbands as respondents so that husband-wife interactions are seen from the wife's point of view, it will be better if seen also from the husband's point of view. The research also uses nonprobability sampling techniques to not generalize the population from the study.

\section{Conclusion and Recommendation}

\section{Conclusion}

The average of husband's income with HEL wife higher than a husband with LEL wife. The average of wife's income in HEL wife higher than LEL wife. The average of family members as many as four people and the number of children as much as two children. Based on the different test result dimension of love/nurturing, there is a significant difference between HEL wife and LEL wife, which is HEL wife has higher score than and LEL Wife in showing affection to husband and love to hug husband. Based on dimension of directing, there is a significant difference between HEL wife and LEL wife in reminding their husband to do the work he had to do, which is LEL wife has higher score than HEL wife. Based on dimension of respect, there is a significant differences between HEL wife and LEL wife, which is HEL wife has higher score than LEL wife in discussing with fine with their husband when she and her husband doesn't agree, feeling that their husband always does what she ask him to do, and inviting her husband/family for recreation together. Almost half sample in the high category in love dimension and directing dimension. Almost half the sample in the moderate category in husband-wife interaction and more than a third of the sample in the high category. The Correlation test shows a significant correlation between husband's age, wife's age, and the number of children with husband-wife interaction. Furthermore, the correlation test also shows that the husband's income significantly correlates with husband-wife interaction.

\section{Recommendation}

Based on the results obtained from the research, the researcher provides several suggestions, namely 1) the next researcher can include the husband as a respondent and can measure parent-child interactions so that they can measure the interactions that exist within the family, 2) the government is expected to implement compulsory education program especially for women so that can improve intellectuality of women so that wives can optimize their ability to interact with family members, 3) NGOs provide activities that increase the wife's intellectual ability in language, express feelings, and interact interpresonally, especially with her husband; 4) the husband can increase his 
income in various ways, husbands and wives also can increase their respect for their partners by praising each other, besides that it is hoped that they can do couple time so that the interaction that is built between husband and wife increases.

\section{References}

Aldous J. 1977. Family interaction patterns. Annual Review of Sociology. 3(1):105135.doi: https://doi.org/10.1146/annurev.so.03.080177.000541

Anhusadar, L.A. (2020). Persepsi mahasiswa PIAUD terhadap kuliah online di masa pandemi COVID-19. Kindergarten: Journal of Islamic Early Childhood Education, 3(1), 44-58. doi: http://dx.doi.org/10.24014/kjiece.v3i1.9609.

Baernholdt, M., Yan, G., Hinton, I., Rose, K., \& Mattos, M. (2012). Quality of life in rural and urban adults 65 years and older: findings from the national health and nutrition examination survey. The Journal of Rural Health, 1-9. doi: 10.1111/j.1748-0361.2011.00403.x

Badan Pusat Statistik [BPS]. 2020. Tingkat Pengangguran Terbuka (TPT) sebesar 4,99 persen. Retrieved from https://www.bps.go.id/pressrelease/2020/05/05/ 1672/februari-2020--tingkat-pengangguranterbuka--tpt--sebesar-4-99-persen.html

Brown, S.M., Doom, J.R., Lechuga-Pe na, S., Watamura, S.E., Kopples, T. (2020). Stress and parenting during the global COVID-19 pandemic. Child Abuse \& Neglect. doi: 10.1016/j.chiabu.2020.104699.

Eliana, N., \& Ratina, R. (2007). Faktor-faktor yang memengaruhi curahan waktu kerja wanita pada PT. Agricinal kelurahan bentuas Kecamatan Palaran Kota Samarinda. Jurnal Ekonomi Pertanian, 4(2), 11-18. Retrieved from: http://agb.faperta.unmul.ac.id/academik/jurnal-ekonomi-pertanian-danpembangunan/

Gambin, et al. (2020). Factors related to positive experiences in parent-child relationship during the COVID-19 lockdown. The role of empathy, emotion regulation, parenting self-efficacy and social support. doi: 10.31234/osf.io/yhtqa.

Graber, E. C., Laurenceau, J.-P., Miga, E., Chango, J., \& Coan, J. (2011). Conflict and love: Predicting newlywed marital outcomes from two interaction contexts. Journal of Family Psychology, 25(4), 541550. https://doi.org/10.1037/a0024507

Hastuti, D. (2015). Pengasuhan: teori dan prisip serta aplikasinya di Indonesia. Bogor, ID: IPB Press.

Herawati, T., Kumalasari, B., Musthofa., \& Tyas, F. P. S. (2018). Dukungan sosial, interaksi keluarga, dan kualitas perkawinan pada keluarga suami istri bekerja. Jurnal Ilmu Keluarga dan Konsumen, 11(1), 1-12. doi: 10.24156/jikk.2018.11.1.1.

Iversen, V., Jackson, C., Kebede, B., Munro, A., \& Verschoor, A. (2011). Do spouses realize cooperative gains? Experimental evidence from rural Uganda. World Development, 39(4), 569-578.

Jeniu, E., Widodo, D. \& Widiani, E. (2017). Hubungan pengetahuan tentang autism dengan tingkat kecemasan orang tua yang memiliki anak autisme di Sekolah Luar Biasa Bhakti Luhur Malang. Nursing News, 2(2), 32-42.doi: https://doi.org/10.33366/nn.v2i2.445 
[Kemenkes] Kementerian Kesehatan. (2020). Pedoman kesiapsiagaan menghadapi Coronavirus Disease (COVID-19) Revisi ke-3. Jakarta (ID): Direktorat Jenderal Pencegahan dan Pengendalian Penyakit.

Larasati RN. (2013). Nilai-nilai keluarga, interaksi keluarga dan potensi perdagangan manusia (kasus di Kabupaten Cianjur) (skripsi). Institut Pertanian Bogor, Bogor, Indonesia.

Masturi, A. (2010). Membangun relasi sosial melalui komunikasi empatik (perspektif psikologi komunikasi). KOMUNIKA: Jurnal Dakwah dan Komunikasi, 4(1), 1431. Retrieved from: http://ejournal.iainpurwokerto.ac.id/index.php/komunika/article/view/135

Mustajab, D., Bauw, A., Rasyid, A., Irawan, I., Akbar, M. A., \& Hamid, M. A. (2020). Fenomena bekerja dari rumah sebagai upaya mencegah serangan COVID-19 dan dampaknya terhadap produktivitas kerja. TIJAB: The International Journal of Applied Business. doi: 10.20473/tijab.V4.I1.2020.13-21

Puspitawati, H. (2012). Gender dan Keluarga: Konsep dan Realita di Indonesia. Bogor (ID): IPB Press.

Puspitawati, H., \& Setioningsih, S. S. (2011). Fungsi Pengasuhan dan Interaksi dalam Keluarga Terhadap Kualitas Perkawinan dan Kondisi Anak pada Keluarga Tenaga Kerja Wanita (TKW). Jurnal Ilmu Keluarga dan Konsumen, 4(1):11-20,DOI: http://dx.doi.org/10.24156/jikk.2011.4.1.11

Rachman, Y. A. (2019). Pengaruh Interaksi Suami-Isteri, Interaksi Orangtua-Anak, Interaksi Teman Sebaya, dan Resiliensi Remaja (Doctoral dissertation), Institut Pertanian Bogor, Bogor, Indonesia.

Rizkillah, R., Sunarti, E., \& Herawati, T. (2015). Kualitas perkawinan dan lingkungan pengasuhan pada keluarga dengan suami istri bekerja. Jurnal Ilmu Keluarga \& Konsumen, 8(1), 10-19.

Rustan, A. S. (2015). Menjalin Hubungan (Relation) dalam Perspektif Komunikasi Efektif. KOMUNIDA: Media Komunikasi dan Dakwah,5(1), 78-90.doi: https://doi.org/10.35905/komunida.v5i1.80

Sholichah, N., \& Anjarwati, R. (2015). Hubungan tingkat pendidikan dengan tingkat kecemasan wanita usia 40-50 tahun dalam menghadapi menopause. Jurnal Komunikasi Kesehatan, 6(20).Retrieved from: http://e-journal.akbidpurworejo.ac.id/index.php/jkk11/article/view/82/82

Sunarti, E., Rizkillah, R., Hakim, F. A., Zakiya, N., \& Damayanti, R. (2021). Manajemen sumber daya keluarga, konflik kerja-keluarga, dan tugas keluarga. Jurnal Ilmu Keluarga \& Konsumen, 14(1), 1-13.doi: https://doi.org/10.24156/jikk.2021.14.1.1

Tyas, F. P. S., Herawati, T. (2017). Kualitas pernikahan dan kesejahteraan keluarga menentukan kualitas lingkungan pengasuhan anak pada pasangan yang menikah usia muda. Jurnal Ilmu Keluarga dan Konsumen, 10 (1): 1- 12,DOI: http://dx.doi.org/10.24156/jikk.2017.10.1. 1

Waldinger \& Schulz. (2006). Linking hearts and minds in couple interactions: intentions, attributions, and overriding sentiments. Journal of Family Psychology, 20(3): 494-504, doi: 10.1037/0893-3200.20.3.494

Wheatley, D. (2014). Travel to work and subjective well being: Astudy of UK dual career households. Journal of Transport Geography. 39: 187-196, DOI: https://doi.org/10.1016/j.jtrangeo.2014.0 7.009 
Williamson, H. C., Karney, B. R., \& Bradbury, T. N. (2013). Financial strain and stressful events predict newlyweds' negative communication independent of relationship satisfaction. Journal of Family Psychology, 27(1), 6575. https://doi.org/10.1037/a0031104

Yoo, H., Bartle-Haring, S., Day, R. D., \& Gangamma, R. (2014). Couple communication, emotional and sexual intimacy, and relationship satisfaction. Journal of sex \& marital therapy,40(4), 275-293.doi https://doi.org/10.1080/0092623X.2012.751072

Zhafirah, Z. (2020). Komunikasi Antarpribadi Pasangan Suami Istri Bahagia Studi Interaksi Simbolik pada Pasangan Suami Istri. Jurnal Penelitian dan Pengembangan Sains dan Humaniora,4(2), 97-108.doi: 10.23887/jppsh.v4i2.27222

Zhang, X. (2012). The effects of parental education and family income on motherchild relationships, father-child relationships, and family environments in the people's republic of China. Journal of family Process, 51(4), 483-497. 